Ingrid Eikeland is a Ph.D. candidate at the Section for Learning and Teacher Education, Norwegian University of Life Sciences. Her Ph.D. focuses on science centres, controversial issues and collaborative research. The Ph.D. is based within the research and development project on science centres called Expand (UtVite).

Merethe Frøyland is the leader of the Norwegian Centre for Science Education ("Naturfagsenteret") at the University of Oslo. She has many years of experience with the research and development of meaningful outdoor science activities in schools (fieldwork, museums, science centres and industry).

\title{
INGRID EIKELAND
}

Section for Learning and Teacher Education, Norwegian University of Life Sciences, Norway ingrid.eikeland@nmbu.no

\section{Pedagogical considerations when educators and researchers design a controversy-based educational programme in a science centre}

\begin{abstract}
This article reports from a 1,5 yearlong co-design process where mainly one researcher and four science centre educators collaboratively designed a controversy-based educational programme for upper secondary school in a Norwegian science centre. Its aim was to contribute to our understanding of the transition in science centres from embracing neutral, science facts, to invite visitors to discuss and think critically about contemporary issues. The data for this study consists of sound recordings from one group interview, eight workshops and three informal meetings. In the analysis, we identified barriers related to both choosing a controversial issue and choosing pedagogical activities. For example, to address an issue that was both science and society based, and finding ways to engage students in discussion. Based on our findings, we recommend paying special attention to the role of sparking students' emotional engagement, the aspect of no right or wrong answer, and the balance between hands-on activity and dialogue when designing controversy-based activities in these institutions.
\end{abstract}

\section{INTRODUCTION}

In this study, researchers engaged a group of science centre educators in a co-design process where we collaboratively designed an educational programme focusing on a controversial issue. The concept 'controversial issues' was selected by the researchers before initiating the co-design process, to promote a transition in science centres from embracing neutral, science facts, to invite visitors to discuss 
and think critically about contemporary issues, a focus that is also called for in science centres and museums (e.g. Allen \& Crowley, 2014; Cameron, Hodge \& Salazar, 2013; Pedretti, 2018; Quistgaard \& Kahr-Højland, 2010; Skydsgaard, Andersen \& King, 2016).

Previous research has documented both challenges and positive outcomes from address controversial issues in science centres. For example, researchers have illustrated that addressing controversial issues could be challenging due to, for example, the complexity of these issues (Allen \& Crowley, 2014; Delicado, 2009; Henriksen \& Frøyland, 2000; Pedretti, 2002). However, other studies have illustrated valuable outcomes for visitors of science centres and museums that have been able to address contemporary issues (Allen \& Crowley, 2014; Navas-Iannini \& Pedretti, 2017; Pedretti, 2004; Quistgaard \& Kahr-Højland, 2010). With a co-design approach, our aim was to provide a detailed insight into different pedagogical considerations when designing controversy-based educational programmes in science centres and museums.

In the next section, we clarify our understanding of the term 'controversial issues' and provide a literature review of science centres related to possibilities and challenges of addressing controversial issues.

\section{The controversial issues concept}

The authors' understanding of the concept 'controversial issues' derives from science education literature on scientific controversies and socio-scientific issues (SSI). We see controversial issues as not having a right or wrong answer but for which different viewpoints could be equally justifiable and discussable (Oulton, Dillon, \& Grace, 2004). Nuances of how to characterise different science-based controversial issues have also been identified. They can be grouped according to whether the science community is settled or not; for example, Hodson (2013) suggested grouping them into those that are "internal" or "external" to science, i.e. whether the controversy exists within science or elsewhere, like social, political, economic, cultural or religious areas. A similar distinction exists where socioscientific issues are grouped as either "ready-made science" or "science-in-the-making", where readymade science means that the science community is settled, and science-in-the-making means that it is not, also referred to as the frontier of science research (Kolstø, 2001; Sadler, Barab, \& Scott, 2007). Due to our focus on no right or wrong answer, we emphasised issues where both the scientific and social dimensions of an issue are questioned (Sadler et al., 2007), also seen as controversial issues that are both internal and external to science, focusing on science-in-the-making.

In addition, we emphasised the pedagogical value of addressing controversial issues. By this, we considered the addressing of controversial issues as a means to engage visitors in discussion and decision-making processes related to contemporary issues, rather than to learn specific content (Oulton et al., 2004; Zeidler \& Nichols, 2009). Oulton et al. (2004) argued that "developing a generic understanding of the nature of controversy and the ability to deal with it is more important than developing pupils' understanding of a particular issue per se" (p. 415).

To sum up, we see controversial issues as having no right or wrong answers where both the scientific and social dimensions are questioned. Furthermore, we see the addressing of controversial issues as a means to engage visitors in discussion and decision-making processes related to contemporary issues. In the next sections, we look into how these elements relate to the science centre context.

\section{Science centres and controversial issues}

A science centre is an interactive museum where students learn science through exploration of and physical interaction with scientific phenomena (Beetlestone, Johnson, Quin, \& White, 1998). They were initially built with the intention of making science accessible to visitors and to increase visitors' scientific knowledge. In addition, the aim was to give visitors positive experiences with science by promoting science as something fascinating, wonderful, easy and fun (Beetlestone et al., 1998; Tlili, Cribb, \& Gewirtz, 2006). 
In later years, different research communities have criticised science centres for presenting science in 1) an overly optimistic and unproblematic way by mainly focusing on the "wonders of science", 2) an authoritative and positivistic way by focusing on science as facts and definite truths and 3) $a$ decontextualized way by focusing on scientific phenomena and principles isolated from society (Beetlestone et al., 1998; Pedretti, 2002; Quistgaard \& Kahr-Højland, 2010). It has further been argued that instead of the science centre seeing their role as just informing the public on an issue, visitors should also be empowered to actively engage in discussions on how to solve contemporary issues concerning their lives (Christensen, Bønnelycke, Mygind, and Bentsen, 2016).

However, studies have also reported that a majority of science centers continue to present scientific facts and phenomenon in an unproblematic way (Christensen et al., 2016; Davidsson \& Jakobsson, 2007; Persson, Ødegaard, \& Nielsen, 2009). For example, as Christensen et al. (2016) evaluated different science centre exhibitions that focused on health, they found that most of them had clear outcomes in mind, e.g. to "change [visitors'] attitudes towards a specific goal (drink more water, wash hands, making healthier food choices, for example)" (p. 40). To understand why science centres and museums keep away from controversial issues, different studies have documented staffs' perceptions of addressing controversial issues in their institutions. These studies reported a number of worries expressed by staff, for example, that the issues are easily outdated (Delicado, 2009; Henriksen \& Frøyland, 2000; Rennie \& Williams, 2002), that the subject matter of controversial issues is often too complicated for visitors to handle (Pedretti, 2002), that it is not as easy to find hands-on activities related to controversial issues as it is with more phenomenon-based content (Pedretti, 2002) or that visitors would need a significant amount of information and might lack sufficient background knowledge to engage in science-related issues (Delicado, 2009; Pedretti, 2002). In addition, it has been expressed worries that addressing controversial issues could create scepticism and confusion towards science among visitors (Allen \& Crowley, 2014; Delicado, 2009; Henriksen \& Frøyland, 2000; Pedretti, 2002), something that would conflict with visitors' expectations of being given reliable information by these institutions (Allen \& Crowley, 2014; Henriksen \& Frøyland, 2000).

These studies show that addressing controversial issues in science centres and museums is not a straightforward task. However, other studies have also examined benefits of engaging visitors in controversial issues and exemplified how this could look like.

\section{Controversy-based exhibitions and educational programmes}

To study the benefits of addressing controversial issues in science centres, Pedretti (2004) conducted a case study on five controversy-based exhibitions at different science centres by studying visitors' experiences. From these responses, she concluded that controversy-based exhibitions are beneficial due to their potential to personalise the subject matter, evoke emotions, stimulate dialogue and debate and promote reflexivity among visitors.

Evoking emotions is seen as especially beneficial for creating discussion and for visitors to care about the controversial issue (Navas-Iannini \& Pedretti, 2017). Within science education, the importance of evoking emotions related to controversial issues is also highlighted. For example, Hodson (2014) argue within SSI that "making these issues real means finding ways to stimulate, provoke, irritate, offend, outrage, amuse or delight students as a way of gaining their attention and building involvement and commitment" (p. 77). Furthermore, Hodson (2014) argued that the emotional engagement needs to be linked to agency and hope: "we need to find ways to make the impact more real, to precipitate feelings of fear, anger, sadness, pain, empathy, compassion and guilt, and to link them to positive feelings of agency, control and empowerment" (p. 77). A focus on emotional engagement and agency when addressing controversial issues is also highlighted by Navas-Iannini and Pedretti (2017).

Engaging visitors in dialogue and democratic processes related to controversial issues has been highlighted in several studies, especially promoting exhibitions and educational programmes with an open-ended outcome. For example, Allen and Crowley (2014) worked with a group of museum staff 
to promote addressing climate change in natural history museums. In this study, they especially highlighted learner autonomy, conversation and reflection and deep investigation as ways to engage visitors in the climate change issue. Quistgaard and Kahr-Højland (2010) studied the potential for using different technological tools when addressing controversial issues in science centres and especially emphasised open-ended exhibitions that aimed to spark visitors' reflections rather than to provide definite truths. Navas-Iannini and Pedretti (2017) studied students' interactions with a controversybased exhibition on teenage pregnancies. They found that the exhibition-design emphasised democratic practices where visitors' voices were heard and responded to in a multidirectional and openended environment, and generating opportunities for visitors to share personal stories.

The studies in this section suggest that elements like evoking emotions, including a personal angle, creating discussion and having an open and visitor-centred angle are beneficial when designing controversy-based exhibitions and educational programmes.

\section{STUDYING THE DECISION-MAKING PROCESS}

The above literature illustrates that both challenges and beneficial outcomes exist when wanting to address controversial issues. However, based on the above literature review, we see that a transition towards address controversial issues in science centres might not be a straight-forward task. In Figure 1, we illustrate how the science centre tradition could be seen as differing from the addressing of controversial issues, and differing from what several researchers call upon in science centres (e.g. Allen \& Crowley, 2014; Cameron et al., 2013; Pedretti, 2018; Quistgaard \& Kahr-Højland, 2010; Skydsgaard, Andersen \& King, 2016). To address controversial issues includes a shift from a focus on facts and scientific phenomenon, often lacking a societal context, towards addressing contemporary, societybased issues without a clear right or wrong answer. It also includes a transition from mainly focusing on bodily experience, towards activities that emphasise dialogue and discussion (see Figure 1).

Science centre tradition
"Wonders of science"
Fact oriented
Decontextualized science
Bodily interactive

Addressing controversial issues

Science in a critical view

No right or wrong answer

Science in a society context

Dialogue and discussion

Figure 1. A transition in science centres from embracing neutral, science facts, to invite visitors to discuss and think critically about contemporary issues.

As researchers, our interest lays in studying this transition towards controversial issues, to study the barriers that we meet, but also possible solutions to the barriers. Our contribution adds to the literature by providing a detailed description of pedagogical considerations that occurred while codesigning a controversy-based educational programme for upper secondary school in a science centre. Studying the decisions made in a design process of exhibitions is also recommended by Mortensen (2010), as she argues that this would provide unique insight into why specific content and designs was chosen or not chosen, elements that would be more implicit when studying a final product. Therefore, we ask:

- What barriers did educators and researchers meet when designing a controversy-based educational programme in a science centre, and how were they dealt with? 


\section{METHODS}

\section{Research design}

Our research approach was based on principles from collaborative design. In co-design, the element of designing a concrete product is seen as a means to create dialogue and reflections among different participants related to a specific issue (Sanders \& Stappers, 2008; Stuedahl, 2019). Our co-design process was based around a 1.5 year-long process (from May 2014 to February 2016) in which mainly one researcher (first author of this paper) and four science centre educators collaboratively designed a controversy-based educational programme for upper secondary school in a Norwegian science centre. Second author of this paper also participated in parts of the co-design process to support first author and to familiarize with the context. The research was connected to the national research project EXPAND which aimed to develop an understanding of learning in science centres in close collaboration with practice (Stuedahl, Frøyland \& Eikeland, 2014).

The educators were essential in this study, as they are typically the ones who develop and carry out the educational programmes in science centres (Tran \& King, 2007). First author was a PhD student in science education with a background in science teaching. Second author, who was supervisor for first author, also had a background in science education, with previous research experience related to addressing controversial issues in museum settings. The educators had varying backgrounds spanning school teaching, nursing and health communication, science research, and design and management. Thus, the group consisted of participants with varying background experiences ranging from different work experience and educational backgrounds to different subject expertise and different experiences with addressing controversial issues.

The co-design process was mainly driven by eight workshops conducted at the science centre. For an overview of the whole co-design process, see Figure 2.

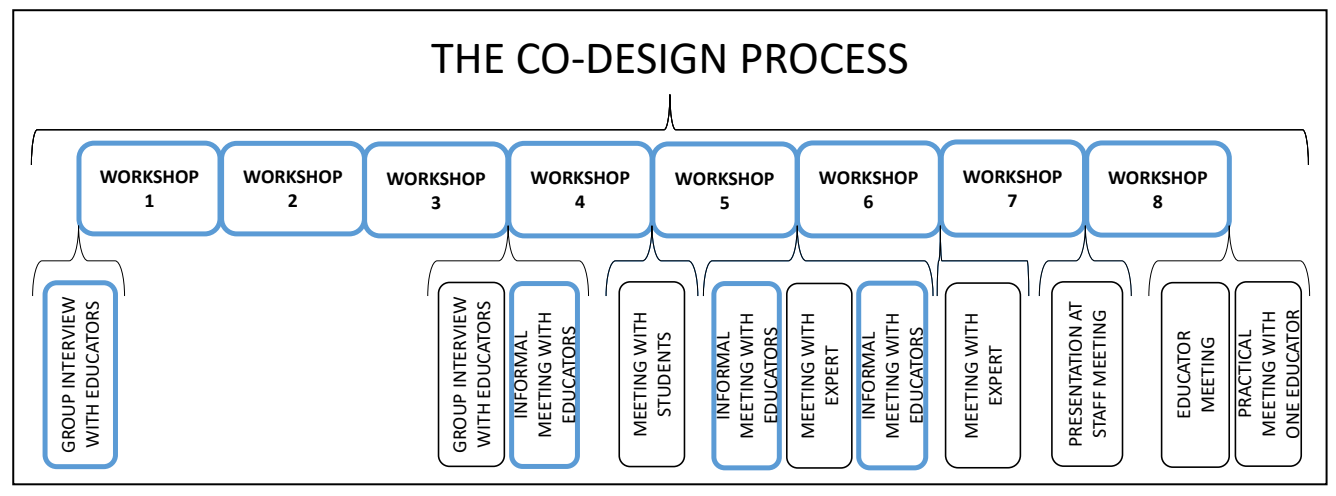

Figure 2. An overview of the co-design process, where the blue squares make up the data for this study.

In this study, we focus on the data from the workshops, first group interview and informal meetings with the educators, as this was where the final decisions related to the educational design took place. The intention with the first group interview was to get familiar with educators' practice and perceptions of controversial issues (see interview guide, Appendix 2). The workshops lasted for one to two and a half hours with approximately two months between each meeting. Through this process, we negotiated our understanding of the concept 'controversial issues' and the aims for the educational programme, in addition to choosing a controversial issue and pedagogical activities that responded to our aims and intentions. Different brainstorming processes framed the meetings where first author worked as a facilitator of the process, responding to the current needs through the co-design process 


\section{Pedagogical considerations when educators and researchers design a controversy-based educational programme in a science centre}

(for more details on the co-design approach, see Eikeland \& Stuedahl, in process). The object of the informal meetings was to keep a continuity in the co-design process during a period in which the educators were prevented from engaging in full workshops. Thus, the informal meetings were less structured than the workshops, but still focused on designing the educational programme. A detailed overview of the data collections included in this study, when they were carried out, who participated and focus of each meeting could be found in Appendix 1.

The educational programme followed the frames for educational programmes at the science centre, understood as lasting for 90 minutes and being curriculum-based. The science centre had separate rooms available for educational purposes; therefore, the educational programme was conducted away from the exhibition area.

\section{Analytical approach}

The data for this study consisted of audio recordings from the first group interview, workshops and informal meetings. The analysis followed the steps described by Braun and Clarke (2006), moving from descriptive to interpretive analysis. The aim of the descriptive analysis is to familiarize with the data and to start generating initial codes. In the interpretive analysis, the aim is to look in-depth at the initial codes for deeper meanings and implications (ibid.). In the following section, the different steps in our analysis are elaborated on.

In the descriptive analysis, carried out in two steps, the researchers were interested in identifying the pedagogical considerations that arose through the co-design process. The first step was carried out as a continuing process through the co-design process. Within 1-2 weeks after each data collection, first author listened to the sound recordings once or twice and wrote an extended summary from the conversations (5-10 written pages with keywords and short sentences). The extended summaries were further transferred to and analysed in the qualitative analysis program NVivo. The data were processed by the researchers between each data collection, grouping the data in broad codes like e.g. "suggested controversial topics", "suggested activities" and "science centre specific". We further identified nuances within the broad codes. For example, within the code "science centre specific", we identified that "hands-on", "personally relevant" and "motivate and engage" were important elements. Through the co-design process, the preliminary findings were also presented to the educators to get correction and feedback on the initial findings.

In the second step, the first group-interview and workshop 1 was transcribed as a whole to secure the validity of the analysis. Additional descriptive analysis were carried out based on the transcripts. The remaining data were listened to and coded directly and selectively transcribed in NVivo. This step provided the researchers with a more in-depth understanding of different nuances and dynamics in the conversations, compared to what was possible based on the extended summaries.

In the third step, the researchers went into an interpretive analysis process by starting to look for deeper meanings and relations between the generated codes. This process was especially guided by our research question, looking to identify significant barriers, often identified as conflicting interests between the participants, and how we dealt with them through the co-design process. As a result, we ended up with five identified barriers that was either related to the process of choosing a controversial issue or choosing pedagogical activities (see Table 1).

\section{RESULTS}

Through the co-design process, we identified barriers related to both choosing a controversial issue and choosing pedagogical activities (see Table 1). For example, in choosing a controversial issue, we experienced disagreement as whether to including the science aspect in the controversial issues or not. In choosing pedagogical activities, we discussed how we would enable students to engage in discussion and decision-making related to a problematic and complex issue like bacterial resistance (the issue we eventually decided to address). 
Table 1. An overview of identified barriers related to choosing a controversial issue and choosing pedagogical activities.

\begin{tabular}{|l|l|}
\hline Pedagogical considerations & Barriers \\
\hline Choosing a controversial issue & $\begin{array}{l}\text { There was a disagreement as whether to including the science } \\
\text { aspect in the controversial issue or not. }\end{array}$ \\
\hline A science and society based issue & $\begin{array}{l}\text { We struggled to find the disagreements related to science within } \\
\text { a controversial issue. }\end{array}$ \\
\hline answer & Choosing pedagogical activities \\
\hline Sparking an emotional engagement & $\begin{array}{l}\text { There was an expressed emphasis towards sparking an emotional } \\
\text { engagement, at the same time as we worried that this would lead } \\
\text { to a negative experience for the students. }\end{array}$ \\
\hline $\begin{array}{l}\text { Facilitating students' discussion } \\
\text { and decision-making process }\end{array}$ & $\begin{array}{l}\text { We were hesitant as to whether we could enable students } \\
\text { to engage in discussion and decision-making related to the } \\
\text { controversial issue. }\end{array}$ \\
\hline Sparking dialogue & $\begin{array}{l}\text { There was a conflict between wanting to focus on hands-on } \\
\text { activities and to engage students in discussion and decision- } \\
\text { making processes. }\end{array}$ \\
\hline
\end{tabular}

In the results, these barriers will be elaborated on, followed by illustrating how we tried to deal with them through the co-design process. In the results, the name of the educators has been changed for anonymity purposes.

\section{Choosing a controversial issue}

In general, when choosing a controversial issue, we experienced worries related to the controversial issue easily becoming outdated. This was especially problematic when we considered addressing the Ebola outbreak in the final programme. We also constantly discussed whether the controversial issues we considered would be personally relevant for the students. However, more prominently, we experienced barriers related to finding an angle for the controversial issue that would be science and society based and without a clear right or wrong answer.

\section{A science and society based issue}

In the initial stages of finding a controversial issue, a special interest was expressed in wanting to address quite sensitive and provocative topics like racial segregation, creationism or death penalty. First and foremost, this could be seen as a communicational issue on how to understand the 'controversial issue' concept by relating to issues that are usually not talked about in society, as illustrated in the following excerpt;

Sara: And then to bring up debates that we do not really want to talk about [...] maybe we should dare to talk about death!

Martin: Oh, that would be the ultimate taboo!

However, as researchers, we also observed that the focus on provocative issues turned into a main focus on moral and ethics, and where scientific and currently relevant issues like climate change, genetically modified organisms, and nutrition and health were overshadowed. To balance this focus, 
the researchers asked the group to consider controversial issues that were less "hot", understood as issues where the moral and ethical aspects were downplayed, and where the scientific aspect was more prominent.

This suggestion was met with scepticism from the group. First of all, the call for a larger focus on the scientific aspect seemed to be associated with controversial issues that exist within scientific communities, such as those related to string theory within quantum physics. Such issues, it was argued, were too challenging for students to handle in terms of their content.

Martin: Science-based controversies are related to issues like quantum physics.

Rune: Yes, it's kind of "haha, string theory", you know. It takes place on a doctoral level and up. So you have to be up there to even participate in the discussions connected to the controversies that exist today, at least most of them. And it's quite a big leap up to that level.

Second, it was argued that it felt more comfortable to address societal perspectives related to an issue than to focus on the scientific content.

Martin: It already feels a bit easier to move in a direction which is more of an ethical, health and psychological way.

Sara: And that's a bit like where we are today as well, in terms of the programmes we offer. We focus more on attitudes and debates in the programmes.

Rune: Also, to deal with ethics is one of the first things we start to learn. "You should not do that", "Do that", "Behave like that". So everyone knows ethics.

However, to find an issue where students needed to deal with both the scientific and societal aspects of an issue was an important element for the researchers as to transition from a fact-based orientation towards science, often found in science centres. To illustrate this point, one of the researchers presented an example of discussions that might arise in a community from the construction of a new highway.

Ingrid: But, for example, in relation to when they were going to build a new highway close to here, there were probably many discussions about the risk of landslides, how high the road should be, how it affected the local ecology, noise...

Martin: But would there be an exciting version of that issue? [...] Because in that example, the students would just say, "Ohhh, booooring”, you know. However, it is a good example to highlight how the science-based programme could look like, though.

To sum up, there was an expressed worry that to include science in the controversy would be too content challenging, and less relevant and engaging to students. As a compromise, it became an important criteria that the science and society based issue would be experienced as personally relevant and engaging to students. We eventually landed on the bacterial resistance issue, an issue we experienced to be both relevant to students and science -and society based.

\section{The issue having no right or wrong answer}

Another challenge we faced was how we would approach a controversial issue in an educational programme. One suggestion was to choose an angle from which we could correct possible misconceptions that students might have, for example, to provide a more informed image of the Ebola epidemic based on credible sources or to make students aware of the misleading information they often encounter in different media connected to health.

Sara: [...] to make the students aware of what type of information the media is providing them all the time. Last week it said that something was carcinogenic, the next week it is the total opposite. One gets so confused. 
The focus on misconceptions and providing final answers conflicted with the researchers' emphasis on no right or wrong answer to make room for students' opinions, rather than to persuade them about a specific way of thinking. As we expressed this worry to the educators, a counterargument was made that to provide answers could be beneficial in raising students' awareness of these issues.

Martin: If the audience has one opinion, but we believe that we have the correct answer, that it is very likely that we at the science centre are right. [...] Then we could hopefully get the visitors to realise, "Oh, is that what I am eating?". [...] Just to create an awareness around this would be highly beneficial.

Despite these arguments, the researchers considered the element of no right or wrong answer to be fundamental, therefore asking the group to still consider angles for the issue without a clear solution. However, to find an issue without a clear right or wrong answers turned out to be more difficult than expected. Especially, we experienced that the science aspect within our potential issues often seemed to be settled. For example, does not most scientific communities agree that there are health benefits from doing exercise or that the consumption of oil is damaging the environment, as illustrated in the following excerpt:

Martin: But I don't feel that it is considered controversial to claim that we need to reduce the consumption of oil. It is something everyone knows... But the topic is highly relevant, though.

We also experienced this challenge with our final topic, bacterial resistance. We struggled to find the controversy within science related to this issue. For example, is there not a unanimous agreement within science that bacterial resistance and the heavy consumption of antibiotics is a problem? As a solution to this challenge, we went "looking for" the controversy within science related to the issue. Within bacterial resistance, we found that there does exist an ongoing discussion about how we should deal with the bacterial resistance issue, as there are different perceptions, both within society and within different scientific communities, about what the most beneficial and efficient way to deal with this issue would be.

As an additional element, there was an expressed worry that our focus on no right or wrong answer might frighten students and leaving them with a sense of hopelessness. Especially since the consequences of bacterial resistance would drastically affect our health care system. To prevent this, we focused the discussions on how students could deal with the bacterial resistance issue in their daily life, by for example, reducing their antibiotic consumption, travelling less or eating less meat. In this way, we hoped to secure a positive sense of agency and hope among the students.

\section{Choosing pedagogical activities}

As researchers, our emphasis was to engage students in discussion and decision-making processes related to a contemporary issue, providing room for the students to explore and express own opinions. The student-centred focus highly resonated with the educators' practice, as this element was essential when they normally developed educational programmes. When choosing pedagogical activities, we especially discussed how we would enable students to express their own opinions. For example, how much information do the students need about bacterial resistance to be able to discuss the issue? In addition, we especially experienced barriers related to; sparking an emotional engagement, facilitating students' decision-making process and sparking dialogue.

\section{Sparking an emotional engagement}

Through the co-design process, and especially with a focus on the 'controversial issues' concept, there was an expressed emphasis towards educational designs that would be experienced as highly provocative and uncomfortable for the students. This emphasis led us to consider designs that would emotionally engage students. This emphasis could be exemplified by one educator sharing her experience from participating in an educational programme at another Norwegian science centre where the focus was to illustrate the unfair distribution of goods as a consequence of global warming. 
Sara: And then someone was placed inside a small room. Inside the small room, it was incredibly hot, and it was very uncomfortable. Almost all of us were sent there, except three people who were placed outside. Moreover, we stood behind this glass wall, and we were very cramped, and it just got hotter and hotter. In addition, no one got anywhere to sit; we just had to stand there. Meanwhile, the people on the outside, who were just standing and watching us, they got soda, you know. Plenty of space, and they were sitting there enjoying themselves with candy. Eventually, they got questions like, "Do you want to share with the people in the little room?" None of them wanted that. Meanwhile, we were just standing there and were very thirsty. We gradually got really provoked.

The above and similar examples created an engagement in the group towards emotionally based educational designs, by for example treating the students unfairly or to lock them into small rooms. Nevertheless, the emotional focus also led to a worry about affecting the students negatively. This worry especially seemed to be related to the educational programme being conducted in a science centre.

Sara: Yes, engage emotions, but where is the boundary, you know? How much? Because one does not know the experiences of the students coming in here.

Rune: Yes, we need to be careful.

Martin: Yes, because we have the science centre filter. Is that not it? That the students should leave the science centre without any negative emotions.

In addition, as researchers, we experienced the focus on sparking emotional engagement to become the main emphasis, outcompeting other pedagogical considerations like no right or wrong answer and facilitating students' discussion and decision-making. To make rooms for these considerations, we decided to rather consider the emotional element towards the end of the design process.

\section{Facilitating students' discussion and decision-making process}

To include the element of engaging students in discussion and decision-making related to a controversial issue felt like quite an overwhelming task both due to the complexity of an issue, and to enable the students to engage with this complexity. This could be illustrated by one of the educators as we were brainstorming controversies related to bacterial resistance:

Sara: A part of the challenge here, because bacterial resistance is a very complex case, we are sitting here and fumbling in the dark because there are so many things. Can we manage to present such a complex case in a simple way where all students are involved? Will we be able to get the students to think about the complexity in the conflicts? To really understand the conflicts? To create a fruitful dialogue between the students? When I talk about it now, I wonder if we are at all capable of addressing the controversies within the bacterial resistance issue.

To enable students to engage in discussion and decision-making it was suggested to find ways to make it easy for students to have an opinion. At the same time, we did not want to make it too easy for them, as we also wanted the students to experience complexity within an issue. As a response to this, it was suggested that we could create dilemmas in which initial opinions would come easily, but then additional information would be provided that would make the students' decision-making process more complex.

Martin: But it could be easy to have an opinion in the beginning.

Sara: Or we would build up underneath and then increase the reflections, and, thus, it becomes more and more challenging to make up your mind.

Martin: Aha, easy to have a default opinion [...] So it could be something that you immediately would be engaged by, and then you just throw out an opinion, and then suddenly there will be some added factors introduced so that you will be thinking, "Oh, maybe I need to think again". 
We therefore ended up creating dilemmas related to dealing with bacterial resistance issues that were presented as initially easy "yes or no" questions, for example, "Do you want to travel less as a contribution to reducing the development of bacterial resistance?" After deciding yes or no individually, the students had to reach a joint agreement within their group. This was the easy part. However, independently of the groups deciding yes or no, their decision would be challenged by provided envelopes containing a counter-argument. For example, if the group decided that they would travel less to prevent bacterial resistance from spreading, they were provided with additional information telling them that we are still exposed to different bacteria through food and other items that we import.

\section{Sparking dialogue}

Overall, the focus on discussion and decision-making seemed to be in constant conflict with the focus on hands-on activities through the design process. It was argued that a focus on creating discussion would not fit with the science centre practice, as hands-on activities are the main trademark of the science centre.

Rune: But our experience is that for the educational programme to function at the science centre, it has to include a practical element. That the students are actually doing something. So we need to choose a topic where you could relate it to a practical experiment or something.

Martin: Yes, and I guess that is also a "must". An absolute requirement.

Rune: And the experiment should be between two-thirds and three-quarters of the programme.

In contrast, one of the educators, who were mainly connected to the health-related educational programmes at the science centre, had a different perception about discussion-based programmes.

Ingrid (addressed question to Sara): Because my impression is that you have a more positive experiences with discussion-based programmes?

Sara: Yes, absolutely! Because I think that we have a lot of debates in our programmes. We have claims that we put forward that create discussions and where you have to take a position on something. [...] There are an incredible number of ways, methods, which we can use to spark the debates.

Thus, there existed different perceptions of student activity, as either being hands-on and experiment-based or to actively engaging students in reflection and dialogue. In our final design, we tried to combine both understandings.

Rune: As long as it is practical, something that they need to do and further makes them reflect afterwards.

Sara: Well, we could do practical activities in discussion-based programmes too, where you do not necessarily sit down, but where you move between different arenas to create discussions.

Martin: Yes, isn't one of your programmes like that (turned towards Sara)? Where there is not that much activity with concrete objects but still activity-based? So that is also a possibility.

Sara: We have a lot of activities that do not necessarily include experiments.

Rune: Yes, activities. Practical activities where you are using both body and mind.

In our final programme, in the first part, the students were set to engage with concrete objects (petri dishes with bacterial colonies, plaque tablets and a bacterial-puzzle where the students could experiment with different scenarios of how antibiotics could affect the body). In the second part, the students were actively engaged in group discussion and decision-making by creating dilemmas with additional voting cards (yes/no). 


\section{DISCUSSION}

Through this study, we gained insight into different pedagogical considerations in the design process related to addressing controversial issues in a science centre. Our experiences from the co-design process resonate with findings documented by other researchers. As, for example, Henriksen and Frøyland (2000) and Pedretti (2002), we also experienced concern about the topic we chose being easily outdated, for example, when we discussed whether we would address the Ebola epidemic. In addition, like Allen and Crowley (2014) and Pedretti (2004), we also worried that the issue we chose being too challenging for students to handle. As a solution to this latter worry, inspired by Oulton et al. (2004), we tried to reduce the number of concepts and content provided to the students, making more room for the students' voices.

In addition, when finding ways to engage students in discussions, there was expressed concern about the discussions we sparked having an overly pessimistic message, for example, that bacterial resistance will destroy our health care system. To angle the discussions more optimistically, we created dilemmas in which the students had to discuss how they could deal with the bacterial resistance issue in their daily lives, inspired by research that recommended sparking a sense of agency among the students (Hodson, 2014; Navas-Iannini \& Pedretti, 2017).

In addition to the above-mentioned elements, we experienced it to be a quite balancing act to deal with the aspects of sparking emotional engagement, focusing on no right or wrong answer and the relationship between hands-on activity and dialogue. We argue that these elements needs special attention when the aim is to engage students in discussion and decision-making processes related to a contemporary issue.

\section{Controversial issues as a source of emotional engagement}

The potential of controversial issues to spark an emotional engagement among the students was especially emphasised in the initial stages of our co-design process. This emphasis would fit well with the essential desire of science centres to engage visitors (Beetlestone et al., 1998; Tlili et al., 2006). However, we also experienced that this desire turned into an all-consuming focus on finding the most contentious and provocative angle possible. This focus further led to hesitations about whether we dared to be provocative, risking negative experiences for the students. This would also contrast with the intention of science centres to give visitors a fun and positive experience with science (Beetlestone et al., 1998; Tlili et al., 2006). Thus, we worry that an overly focus on sparking emotional engagement through provocations could lead to science centre's choosing to avoid addressing controversial issues overall from fear of reactions from visitors.

We further experienced that the initial focus on sparking emotional engagement outcompeting other pedagogical considerations. Thus, the emotional element was downplayed in our design process, and was almost non-existent in our final educational design. In retrospect, as researchers, we could see that we were possibly too cautious with the provocative and emotional angle, especially due to other researchers highlighting emotional engagement as an important means for creating discussion and for visitors to care about an issue (Hodson, 2014; Navas-Iannini \& Pedretti, 2017). Thus, the source of emotional engagement could have supported our desire to engage visitors in discussions related to contemporary issues. Nevertheless, we still want to raise caution about design-scenarios where sparking emotional engagement turns into a goal in itself.

\section{The aspect of no right or wrong answer}

Our aim was to design a controversy-based educational programme without a right or wrong answer. However, there was also expressed advantages with providing final answers by, for example, addressing the climate change issue in an informed and fact-based way. It was argued that this approach could correct students' misconceptions and to provide them with correct and updated information related to the issue. Despite this advantage, resonating with Christensen et al. (2016), to just inform 
visitors on how to solve an issue would not empower visitors to share own perspectives and experiences. Contrary, Christensen et al. (2016) emphasise educational design without a clear outcome in mind as to invite visitors to express own opinions and to participate in discussions related to contemporary issues. Navas-Iannini and Pedretti (2017) also emphasise controversy-based exhibitions where the outcomes are multidirectional and open ended, making room for visitors' voices. However, they further argue that to provide robust information related to an issue, combined with a multidirectional outcome, could empower visitors' in their decision-making process, without sacrificing an open-ended approach (ibid.). In our design, we created dilemmas where we both provided students with information on bacterial resistance, and at the same time emphasized an open-ended outcome by not guiding the students towards a 'right answer' on how they should deal with the bacterial resistance issue.

Furthermore, when trying to find an angle for the controversial issue without a right or wrong answer, we especially struggled to include science. One of the issues was that we experienced scepticism in the group towards including science in the controversy. In other studies, this scepticism has been linked to staff not wanting to question science in their institutions for fear of disappointing visitors' expecting to being provided with reliable information (Allen \& Crowley, 2014; Henriksen \& Frøyland, 2000). This was not a worry in our study; however, we worried that a science-based controversy would be less relevant and too difficult for students to handle, for example, related to quantum physics, and that it therefore felt easier to leave the science out of the controversy. This science-based understanding of controversial issues could be linked to issues that are either internal or external to science, focusing on ready-made science or science-in-the-making (Hodson, 2013; Kolstø, 2001). In the case of quantum physics, this issue could be seen as mainly being internal to science and lacking the society aspect. Contrary, when we tried to find a suitable controversy that was both science and society based, we experienced many issues to be external to science where the science was ready-made. We also experienced this dilemma with the issue of bacterial resistance. To find an angle where both the science and society aspects were part of the controversy, we had to "go looking for" a suitable angle and ended up with "how to deal with bacterial resistance". Thus, even though we had landed on the bacterial resistance issue, we still had to go some rounds before finding a suitable angle where disagreement was prominent.

We therefore argue that, in a design process, special attention needs to be payed to whether the outcome of the exhibition or educational programme is open-ended, and whether the controversial issue questions both the science and society aspects. From our experience, we especially struggled with the role of science in the controversial issue.

\section{Sparking students' discussions}

Sparking students' discussions was an important element in our final programme. However, we experienced a conflict between focusing on students' discussions and hands-on activities. It was argued that the students could not just sit still and discuss the bacterial resistance issue-they had to do something hands-on for the programme to fit with the science centre context. Understandably, as interactivity is one of the main foundations of the science centre movement (Beetlestone et al., 1998). However, we struggled to find hands-on activities that would fit with the bacterial resistance issue. This challenge is also highlighted in previous literature, suggesting that it is not as easy to find hands-on activities related to controversial issues as with more phenomenon-based content (Pedretti, 2002). We ended up creating an educational programme with one hands-on part that was neutral and phenomenon-based, where students, for example, would study bacterial colonies in Petri dishes, and another part with discussion-based dilemmas focusing on the bacterial resistance issue. However, we had hoped for the focus on the bacterial resistance issue and the hands-on activities to be more intertwined. Nevertheless, we argue that a more intertwined example could be illustrated by one of the educators in this study, where she described an exhibition on climate change designed by another Norwegian science centre (see p. 17). 
As an additional view, Skydsgaard et.al. (2016) makes a distinction between bodily and dialogic interactivity. This distinction could be related to our discussions of student-activity, either perceived as hands-on and experiment-based activities where visitors engage with concrete objects, or where students' actively engaging in reflections and discussions independently of concrete objects. This distinction is useful to have in mind by questioning what role the different aspects should play when addressing controversial issues. For example, studies by Delicado (2009) and Tlili et al. (2006) stress that science centres need to think alternatively to their traditional hands-on approach to make room for dialogue around contemporary issues in their institutions.

\section{CONCLUSION}

This study has provided insight into different pedagogical considerations when designing a controversy-based educational programme in a science centre. By analysing the decision-making process towards a final design, we have gained unique insight into different aspects that could provide direction for science centres' wanting to transition from embracing neutral, scientific facts, to invite visitors to discuss and think critically about contemporary issues. We argue that this study could support and inspire science centre educators, researchers and others in making more deliberate decisions when addressing controversial issues. In this matter, we recommend paying special attention to the nuances of controversial issues as a source of emotional engagement, the aspect of no right or wrong answer and the balance between hands-on activity and dialogue.

\section{REFERENCE LIST}

Allen, L. B., \& Crowley, K. J. (2014). Challenging Beliefs, Practices, and Content: How Museum Educators Change. Science education, 98(1), 84-105. doi:10.1002/sce.21093

Beetlestone, J. G., Johnson, C. H., Quin, M., \& White, H. (1998). The Science Center Movement: contexts, practice, next challenges. Public Understanding of Science, 7(1), 5-22. doi:10.1177/096366259800700101

Braun, V., \& Clarke, V. (2006). Using thematic analysis in psychology. Qualitative research in psychology, 3(2), 77-101. doi:10.1191/1478088706qpo63oa

Cameron, F., Hodge, B., \& Salazar, J. F. (2013). Representing climate change in museum space and places. Wiley Interdisciplinary Reviews: Climate Change, 4(1), 9-21. doi:10.1002/wcc.200

Christensen, J. H., Bønnelycke, J., Mygind, L., \& Bentsen, P. (2016). Museums and science centres for health: from scientific literacy to health promotion. Museum Management and Curatorship, 31(1), 17-47. doi:10.1080/09647775.2015.1110710

Davidsson, E., \& Jakobsson, A. (2007). Different Images of Science at Nordic Science Centres. International Journal of Science Education, 29(10), 1229-1244. doi:10.1080/09500690600969848

Delicado, A. (2009). Scientific controversies in museums: notes from a semi-peripheral country. Public Understanding of Science, 18(6), 759-767. doi:10.1177/0963662508098577

Eikeland I., \& Stuedahl D., (in process). Co-designing a controversy-based educational programme in a science centre. In M. Achiam, J. Dillon, \& M. Glackin, Addressing Wicked Problems through Science Education: The role of out-of-school experiences. Springer.

Henriksen, E. K., \& Frøyland, M. (2000). The contribution of museums to scientific literacy: views from audience and museum professionals. Public Understanding of Science, 9(4), 393-415. doi:10.1088/0963-6625/9/4/304

Hodson, D. (2013). Don’t Be Nervous, Don’t Be Flustered, Don’t Be Scared. Be Prepared. Canadian Journal of Science, Mathematics and Technology Education, 13(4), 313-331. doi:10.1080/1492 6156.2013.845327

Hodson, D. (2014). Becoming part of the solution: Learning about activism, learning through activism, learning from activism. In J.L. Bencze, \& S. Alsop (Eds.) Activist science and technology education (pp. 67-98): Springer. doi:10.1007/978-94-007-4360-1_5 
Kolstø, S. D. (2001). Scientific literacy for citizenship: Tools for dealing with the science dimension of controversial socioscientific issues. Science education, 85(3), 291-310. doi:10.1002/sce.1011

Mortensen, M. F. (2010). Museographic transposition: The development of a museum exhibit on animal adaptations to darkness. Éducation et didactique, 4(1), 115-138. doi:10.400o/educationdidactique. 763

Navas-Iannini, A. M., \& Pedretti, E. (2017). Preventing Youth Pregnancy: Dialogue and Deliberation in a Science Museum Exhibit. Canadian Journal of Science, Mathematics and Technology Education, 17(4), 271-287. dio: 10.1080/14926156.2017.1381285

Oulton, C., Dillon, J., \& Grace, M. M. (2004). Reconceptualizing the teaching of controversial issues. International Journal of Science Education, 26(4), 411-423. doi:10.1080/0950069032000072746

Pedretti, E. (2002). T. Kuhn meets T. Rex: Critical conversations and new directions in science centres and science museums. Studies in Science Education, 37(1), 1-41. doi:10.1080/03057260208560176

Pedretti, E. (2004). Perspectives on learning through research on critical issues-based science center exhibitions. Science education, 88(S1), S34-S47. doi:10.1002/sce.20019

Persson, P.-E., Ødegaard, M., \& Nielsen, S. S. (2009). Evaluering av vitensenterprogrammet. Ekspertgruppens rapport. Retrieved June 18, 2018, from Web site: https://docplayer.me/687355Evaluering-av-vitensenterprogrammet-ekspertgruppens-rapport-per-edvin-persson-marianneodegaard-sigurd-solhaug-nielsen.html.

Quistgaard, N., \& Kahr-Højland, A. (2010). New and innovative exhibition concepts at science centers using communication technologies. Museum Management and Curatorship, 25(4), 423436. doi:10.1080/09647775.2010.525408

Rennie, L., \& Williams, G. (2002). Science centers and scientific literacy: Promoting a relationship with science. Science education, 86(5), 706-726. doi:10.1002/sce.10030

Sadler, T. D., Barab, S. A., \& Scott, B. (2007). What do students gain by engaging in socioscientific inquiry? Research in Science Education, 37(4), 371-391. doi:10.1007/s11165-006-9030-9

Sanders, E. B.-N., \& Stappers, P. J. (2008). Co-creation and the new landscapes of design. Codesign, 4(1), 5-18. doi:10.1080/15710880701875068

Skydsgaard, M. A., Møller Andersen, H., \& King, H. (2016). Designing museum exhibits that facilitate visitor reflection and discussion. Museum Management and Curatorship, 31(1), 48-68. doi :10.1080/09647775.2015.1117237

Stuedahl, D. (2019). Participation in design and changing practices of museum development. In V. Dziekan, K. Drotner, R. Paryy, \& K. Schrøder (Eds.), The Routledge Handbook of museum, media and communication. London: Routledge. doi:10.4324/9781315560168-18

Stuedahl, D., Frøyland, M., \& Eikeland, I. (2014). Expand-Research in Norwegian science centers. Nordisk Museologi (1), 85-94. doi:10.5617/nm.3033

Tlili, A., Cribb, A., \& Gewirtz, S. (2006). What becomes of science in a science centre? Reconfiguring science for public consumption. The Review of Education, Pedagogy, and Cultural Studies, 28(2), 203-228. doi:10.1080/10714410600739921

Tran, L., \& King, H. (2007). The Professionalization of Museum Educators: The Case in Science Museums. Museum Management and Curatorship, 22(2), 131-149. doi:10.1080/09647770701470328

Zeidler, D. L., \& Nichols, B. H. (2009). Socioscientific issues: Theory and practice. Journal of Elementary Science Education, 21(2), 49-58. doi:10.1007/BFo3173684 


\section{APPENDICES}

\section{Appendix 1 An overview of the data collections}

A detailed overview of the data collections included in this study, when they were carried out, who participated and focus of the meetings.

\begin{tabular}{|c|c|c|c|}
\hline When & What & Who & Focus \\
\hline $\begin{array}{l}\text { May } \\
2014\end{array}$ & Group interview 1 & $\begin{array}{l}\text { One researcher, five } \\
\text { educators }\end{array}$ & $\begin{array}{l}\text { The researcher wanted to get insight } \\
\text { into educators' educational practice and } \\
\text { perceptions of controversial issues }\end{array}$ \\
\hline $\begin{array}{l}\text { August } \\
2014\end{array}$ & Workshop 1 & $\begin{array}{l}\text { One researcher, } \\
\text { three educators }\end{array}$ & $\begin{array}{l}\text { Discussed the potential outcome for } \\
\text { students on a controversy-based educa- } \\
\text { tional program }\end{array}$ \\
\hline $\begin{array}{l}\text { October } \\
2014\end{array}$ & Workshop 2 & $\begin{array}{l}\text { Two researchers, } \\
\text { four educators }\end{array}$ & $\begin{array}{l}\text { Decided on the Ebola issue and dis- } \\
\text { cussed the specific content for the school } \\
\text { programme }\end{array}$ \\
\hline $\begin{array}{l}\text { Decem- } \\
\text { ber } 2014\end{array}$ & Workshop 3 & $\begin{array}{l}\text { Two researchers, } \\
\text { three educators }\end{array}$ & $\begin{array}{l}\text { Elaborated on the Ebola issue through a } \\
\text { role play approach }\end{array}$ \\
\hline $\begin{array}{l}\text { February } \\
2015\end{array}$ & Informal meeting 1 & $\begin{array}{l}\text { One researcher, two } \\
\text { educators }\end{array}$ & $\begin{array}{l}\text { Elaborated on the content within the } \\
\text { Ebola issue }\end{array}$ \\
\hline $\begin{array}{l}\text { March } \\
2015\end{array}$ & Workshop 4 & $\begin{array}{l}\text { One researcher, four } \\
\text { educators }\end{array}$ & $\begin{array}{l}\text { Continued elaborating on the Ebola issue } \\
\text { through a role play approach }\end{array}$ \\
\hline $\begin{array}{l}\text { March } \\
2015\end{array}$ & Workshop 5 & $\begin{array}{l}\text { One researcher, four } \\
\text { educators }\end{array}$ & $\begin{array}{l}\text { Changed the topic to bacterial resistance. } \\
\text { Elaborated on the bacterial resistance } \\
\text { issue and pedagogical considerations for } \\
\text { the school programme }\end{array}$ \\
\hline $\begin{array}{l}\text { June } \\
2015\end{array}$ & Informal meeting 2 & $\begin{array}{l}\text { One researcher, four } \\
\text { educators }\end{array}$ & $\begin{array}{l}\text { Elaborated on the current educational } \\
\text { design }\end{array}$ \\
\hline $\begin{array}{l}\text { June } \\
2015\end{array}$ & Informal meeting 3 & $\begin{array}{l}\text { One researcher, one } \\
\text { educator }\end{array}$ & $\begin{array}{l}\text { Unwrapped the bacterial resistance issue } \\
\text { and discussed different dilemmas related } \\
\text { to the issue }\end{array}$ \\
\hline $\begin{array}{l}\text { Septem- } \\
\text { ber } 2015\end{array}$ & Workshop 6 & $\begin{array}{l}\text { One researcher, two } \\
\text { educators }\end{array}$ & $\begin{array}{l}\text { The researcher provided a suggestion for } \\
\text { a final educational programme, based } \\
\text { on our previous discussions through the } \\
\text { co-design process. Discussed practical } \\
\text { considerations related to the educational } \\
\text { programme. }\end{array}$ \\
\hline $\begin{array}{l}\text { October } \\
2015\end{array}$ & Workshop 7 & $\begin{array}{l}\text { One researcher, two } \\
\text { educators }\end{array}$ & $\begin{array}{l}\text { Discussed practical considerations related } \\
\text { to the educational programme }\end{array}$ \\
\hline $\begin{array}{l}\text { January } \\
2016\end{array}$ & Workshop 8 & $\begin{array}{l}\text { One researcher, two } \\
\text { educators }\end{array}$ & $\begin{array}{l}\text { Finished up the program by deciding on } \\
\text { and carrying out practical matters }\end{array}$ \\
\hline
\end{tabular}




\section{Appendix 2 Interview guide - Group interview}

1. About the science centre practice

a. Could you tell a bit about how you usually plan and design new educational programmes here at the science centre?

b. What do you see as being elements that make up a successful educational programme?

2. About controversial issues

a. How do you understand 'controversial issues'? Could you give examples?

b. Do you have any experience with addressing controversial issues at this science centre?

If yes, could you give examples? 